\title{
Longshore patterns of distribution of macroinfauna on a Uruguayan sandy beach: an analysis at different spatial scales and of their potential causes
}

\author{
Luis Giménez*, Beatriz Yannicelli \\ Sección Oceanografía, Facultad de Ciencias Igua 4225, 1400 Montevideo, Uruguay
}

\begin{abstract}
Spatial distribution of macrofauna along the longshore axis was studied on an exposed (Uruguayan) sandy beach in order to assess (1) its dependence on beach topography, and (2) the validity to extrapolate local distribution patterns to larger spatial scales (i.e. km). The distribution of the isopods Excirolana armata and Excirolana braziliensis, the sand crab Emerita brasiliensis and several species of insects was analyzed at 3 spatial scales. A grid sampling was used at small scale (intersample distance: $4 \mathrm{~m}_{i}$ extension sampled: 30 to $40 \mathrm{~m}$ ), a transect design at meso scale (intersample distance 4 to $20 \mathrm{~m}$; extension sampled: 100 to $120 \mathrm{~m}$ ), and random sampling at large scale (intersample distance: $100 \mathrm{~m}$; extension sampled: $3000 \mathrm{~m}$ ). Spatial distribution at small and meso scales were described using autocorrelation functions, and tested for effects of topography at meso and large scales using ANOVA and paired $t$-tests. We found that at small and meso scales the distribution of E. armata and E. brasiliensis was patchy and affected by cusp topography. At large scales, the effect of cusp topography was restricted to E. armata. E. armata and E. brasiliensis showed large-scale aggregations, and E. braziliensis and insects showed large-scale patchiness associated with longshore variability in sediment water content and dune characteristics. We conclude that cusp topography affects longshore distribution patterns, and that it is not valid to extrapolate local longshore distribution to larger scales for every species. We suggest that different processes affecting spatial distribution must be operating at different scales. At small scales, patterns of distribution may be affected by swash transport of food and/or organisms, involving factors such as beach topography, swash and animal movements. At larger scales, in addition to larval and food supply, sediment transport by the wind would play an important role. Spatial patterns of sand transport by the wind may be affected by longshore changes in vegetation cover on the dune field. We further suggest that there may be a link between the beach and the dune habitats operating at large spatial scales.
\end{abstract}

KEY WORDS: Sandy beach $\cdot$ Multiscale $\cdot$ Spatial distribution $\cdot$ Emerita $\cdot$ Excirolana

\section{INTRODUCTION}

Marine as well as terrestrial ecologists have long recognized that organisms are distributed in patch mosaics (see Picket \& White 1985). However, not until the 1980 s did ecologists realize that the distribution patterns and their generating processes were scaledependent (see Wiens et al. 1986, Levin 1992 for discussion). An important consequence of such findings is that the results and conclusions of an ecological

*E-mail: jluis@fcien.edu.uy study depend on the spatial and temporal scales analyzed (Wiens et al. 1986). An interesting example is that of the benthic communities of marine rocky shores. During the 1960s and 1970s most work was at small spatial scales and it was concluded that spatial distribution and community structure were mainly determined by biological interactions such as predation, competition, and physical disturbance (see Connell 1961, Paine 1974, Paine \& Levin 1981). Later, many studies during the 1980 s and 1990 s, made at larger scales, showed that larval transport and supply (Roughgarden et al. 1988) as well as spatial variability in phytoplankton abundance (Duggins et al. 1989, 
Menge et al. 1997) may play the most important role in generating large-scale patterns. One way to avoid wrong generalizations of a 'scale-dependent conclusion' seems to be to perform ecological studies simultaneously at different spatial and/or temporal scales. This approach may determine if distribution patterns and associated processes are scale dependent, and it possibly helps to understand ecological communities in a broader way (Wiens et al. 1986, Wiens 1989). Recently, there has been an increasing number of studies whose approach to the question of distribution patterns of community structure and processes include sampling programs and/or field experiments performed at different spatial scales. In benthic ecology, this work has mostly focused on rocky shores (Underwood \& Chapman 1996, Aberg \& Pavia 1997), coral reefs (Connell et al. 1997) and soft bottoms from the subtidal or sandflats (McArdle \& Blackwell 1989, Jones et al. 1990, Morrisey et al. 1992a, Thrush et al. 1997a and references therein).

In exposed environments, such as sandy beaches, most work has been traditionally focused on zonation patterns along the dune-swash axis (see McLachlan \& Jaramillo 1995 for review, Brazeiro \& Defeo 1996, Giménez \& Yannicelli 1997), or on the morphodynamical state of different beaches (McLachlan 1990, Defeo et al. 1992, Jaramillo \& McLachlan 1993, Giménez \& Yannicelli 1997). Zonation studies deal with physical or biological processes acting at scales between a few to tens of meters (see Brown \& McLachlan 1990, Defeo 1996a). Comparisons between beaches with different morphodynamical states cover larger spatial scales, where physical features such as grain size, beach slope and swash climate play the most important structuring role (McLachlan 1988, 1990, 1996). They did not however explicitly address questions about distribution at different spatial scales. Studies explicitly considering spatial distribution patterns in the longshore axis are scarce (McLachlan \& Hesp 1984, Donn et al. 1986, Jaramillo et al. 1994, Lastra \& McLachlan 1996). They stress the role of beach topography, larval transport and settlement as factors regulating infaunal distributions. Only recently has there been an effort to evaluate patterns of population dynamics of sandy beach macrofauna at different spatial scales (Defeo 1993, 1996a, Defeo \& de Alava 1995). These studies suggest that at some spatial scales human activities might affect population dynamics and community structure of sandy beach ecosystems. They also show that a multiscale approach may be very useful to explain longterm trends in macroinfaunal variability. So, it seems that as long as studies of sandy beach communities cover only 1 spatial or temporal scale, our understanding of its structure and dynamics will be far from complete.
In this paper, we address the question of how the macroinfauna distribution patterns on a sandy beach changes at different spatial scales. We suggest potential causing factors and discuss present ideas on this subject. We present a case study where we analyze the spatial distribution of macroinfauna at 3 spatial scales on a Uruguayan sandy beach with a clear longshore topographic pattern. Our objectives were to assess if longshore macroinfauna distribution was patchy associated to longshore topography, and if distribution patterns at smaller scales could be reasonably extrapolated to larger scales.

\section{MATERIALS AND METHODS}

Study site. The study site was 'Sur' beach, a sandy arc situated west of Cabo Polonio, Uruguay (Fig. 1). This is an exposed microtidal (tidal range $<30 \mathrm{~cm}$ ), intermediate-dissipative beach about $120 \mathrm{~m}$ wide. The beach has cusp horns separated by 30 to $60 \mathrm{~m}$, medium to fine sands and a slope of $2.5^{\circ}$ to $8^{\circ}$ (Giménez \& Yannicelli 1997). Beach cusps are rhythmic shoreline features, formed by swash action, and consist of gentle gradient embayments (cusp bays) separated by step gradient horns (Masselink et al. 1997). The most common benthic macroinfaunal species of 'Sur' beach are the isopods Excirolana armata and Excirolana braziliensis, the sand crab Emerita brasiliensis and the wedge clam Donax hanleyanus (Giménez \& Yannicelli 1997).

We analyzed distributional patterns of infauna at 3 spatial scales. In all cases, samples were taken with an $18 \mathrm{~cm}$ diameter corer to a depth of $20 \mathrm{~cm}$; organisms retained after sieving ( $1 \mathrm{~mm}$ mesh) were identified and counted.

Small scale. In order to determine how small-scale species distribution correlates to beach topography, we followed a systematic sampling design. In the smallscale study a sampling unit (SU) consisted of only 1 circular area of $18 \mathrm{~cm}$ diameter (see above). We collected a SU every $4 \mathrm{~m}$ following a grid set between the maximum and minimum reach of the swash and 2 consecutive cusp horns (Fig. 1). The size of the grid changed with sampling occasion (20 to $40 \mathrm{~m}$ length and width), depending on swash conditions. Sampling was performed in February, March and July 1996 at a location $1300 \mathrm{~m}$ west of the rocky peninsula of Cabo Polonio. In March 1996 we also took samples to measure water content of the sediments: the samples were taken with a corer (diameter $=5 \mathrm{~cm}$ ), wrapped in aluminium foil, weighed, dried and weighed again. The percentage of water content of the sediment was estimated as the difference between the wet and dry weights divided by the wet weight of the sample. 
To analyze and map the distribution of species and sediment water content, we used the kriging interpolation technique. For each species we used abundance per SU to calculate variograms and spatial autocorrelation functions (Rossi et al. 1992). To test if variogram functions were significantly dependent on spatial lags (i.e. distribution was patchy), we tested the significance of the parametric correlation coefficient between the lag and the variogram function (Zar 1996). Considering the low number of spatial lags we did not attempt to adjust a particular model to any variogram curve.

Meso scale. We wanted to test if abundance and distribution of a given species was affected by the topographic structure of the beach. In the same location as

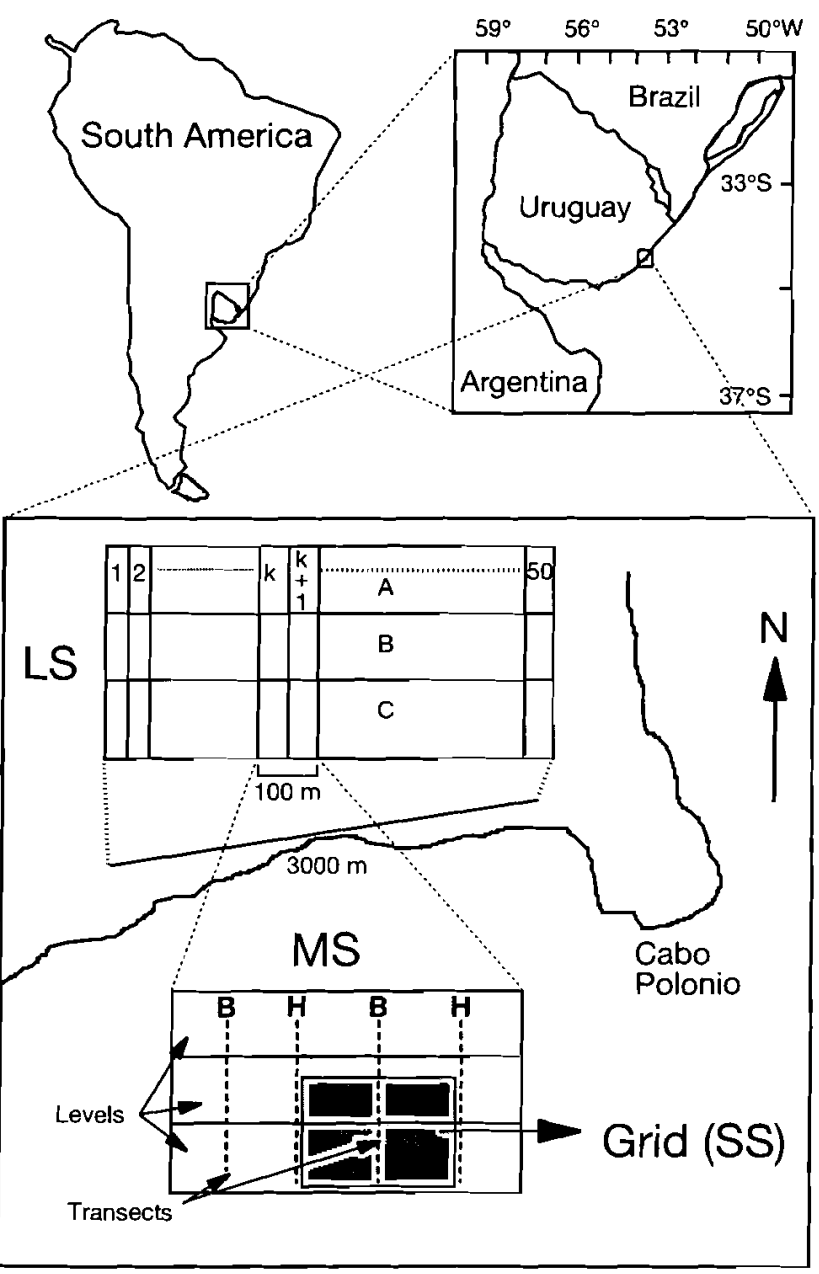

Fig. 1. Geographic location of 'Sur' beach, Cabo Polonio, Uruguay, and sampling sites and designs for small scale (SS) meso scale (MS) and large scale (LS). For MS, letters $\mathrm{H}$ and $\mathrm{B}$ show the transects that were laid in horns and bays respectively. For LS, letters A, B and C indicate beach levels, and subindexes $1,2, k, k+1, \ldots 50$ are rectangles to be randomly selected for sampling. See text for details of the sampling procedure small-scale sampling was performed, 4 transect lines were drawn from the dune line to the lower reach of swash. They were intentionally placed on the bays and horns of 2 consecutive cusp systems (Fig. 1). Transect lines were separated by roughly 20 to $30 \mathrm{~m}$, so the sampling area covered a maximum longshore distance of 60 to $90 \mathrm{~m}$. SUs were collected at stations defined every $4 \mathrm{~m}$, starting with the first station at the dune line. A SU consisted of 2 corer samples taken at each station. As this sampling procedure was carried out nearly once a month, from April 1994 to July 1996, it allowed us to estimate spatial variations for a longer period than the small-scale or the large-scale sampling did.

Data were analysed following 2 different approaches. The first approach had stations as SUs, and it will hereafter be called 'analysis at the scale of the stations'. We expected that a division of the sampling area in strata would reduce the negative effect of species patchiness on the power of the analysis (Morrisey et al. 1992a,b, Underwood \& Chapman 1996, Legendre \& McArdle 1997). A 4-factor between- or within-subject (repeated measures) nested-ANOVA design (Zar 1996) was therefore used to determine if each species abundance depended on the following factors: (1) Structure (2 treatments: cusp horn and bay), (2) Transect ( 2 transects per structure type), (3) Beach level (upper, middle and lower) and/or (4) Occasion. Structure and Transect accounted for longhsore variability. Beach levels divided transects in 3 sectors which differed in their cross-shore physical characteristics. The upper level was flat and dry, and was limited by the dune line and the beginning of the cusp bay. The middle level showed the most pronounced differences regarding cusp topography, it was set between the beginning of the bay and the upper level of the swash zone. The lower level showed little cusp topography and coincided with swash zone. The factors Structure and Level were fixed and orthogonal; Transect was random and nested within Structure. The repeated measurements were made on the factor Occasion.

The second data analysis approach (hereafter called 'analysis at the scale of transects') considered abundance pooled by transect. It has been shown that in a sandy beach the observed patterns of infaunal distribution depend on whether abundance was calculated per station or per transect (Defeo 1996a). For each species, we computed the abundance per transect. A 3-way ANOVA without replication was used to search for significant differences in abundance of a given species among: Structure, Occasion and Geographic Location of the transect (West or East) (Zar 1996).

To assess if the distribution pattern of each of the studied species differed between cusp bay and horn, data from stations of both transects laid in the same 
structure were pooled in a single cross-shore distribution per structure and sampling occasion. We analyzed distributions using autocorrelation functions ( $\mathrm{ACFs}$ ). We adjusted the following model:

$$
\gamma_{a}=a+b \log L
$$

where $\gamma_{a}$ is the autocorrelation, $L$ is the spatial lag (starting at $L=1$ ) and $a$ and $b$ are constants. Then, the curves were compared using ANCOVA. If the slopes of the ACFs were different the test was stopped, but if they were similar we tested for differences in the intercept values.

We also tested if there were shifts in the cross-shore distributions associated with cusp bays and horns. For both horn and bay data, a matrix was constructed with columns representing sampling periods and rows representing stations. A unidirectional cross-correlation function (CCF) between both matrices was calculated where the lag variable was station intervals. For distributions that peaked at the same station, the CCF should have a maximum at lag $=0\left(L_{0}\right)$. If the distribution in the cusp horn was shifted towards or away from the dune line, the peak would be found at some lag different from $0\left(L_{j}\right.$ with $\left.j \neq 0\right)$ (i.e. the r value at $L_{j}$ should be significatively higher than the $\mathrm{r}$ at $L_{0}$ ). To test if the peak of CCF was at $L_{0}$, a Gaussian function was adjusted to the $\mathrm{CCF}$ by nonlinear regression. We only considered values of cross-correlation up to $L=5(L 5)$ because we expected only small shifts in the distributions and we could only use positive values of crosscorrelation to adjust the Gaussian function. The mean value of the Gaussian function was used as an estimation of the maximum value of cross-correlation, that is, the lag where the peaks of both distributions were best correlated. To test if this mean value was different from 0 (i.e. the maximum of $\mathrm{r}$ was not at $L_{0}$ ), we also calculated its confidence interval (CI). We selected the $\mathrm{CI}$ at $99 \%$ so that we could minimize the Type I error: the nonlinear estimation methods always provide asymptotic values, smaller than the real ones (Drapper \& Smith 1981).

Large scale. A beach area of $3000 \mathrm{~m}$ length in the longshore direction was divided into rectangles of $50 \mathrm{~m}$ length; 10 of them were randomly sampled in August 1995 and February 1996 (Fig. 1). The size of the rectangles was set so they would include a cusp horn and bay. Each randomly selected rectangle was divided into 3 cross-shore levels and in 2 longshore subareas each consisting of a cusp horn or a bay. The division of each area in levels reduced spatial variance in the number of individuals, since we knew that species are distributed in zones along the dune-swash axis (Giménez \& Yannicelli 1997).

Five sediment core samples were taken at each level and subarea and pooled as a single SU $\left(0.1 \mathrm{~m}^{2}\right.$ area $)$.
We then obtained 10 pairs of samples at each level to compare number of individuals between cusp horn and bay. We compared the abundance of Excirolana armata with a between- or within-subject (repeated measures) 2-way ANOVA: Structure (horn and bay) and Level (middle and lower) were considered withinsubject factors and Occasion (August 1995 and February 1996) was the between-subject factor. For other species we obtained data only for a single level and occasion. In these cases we used paired $t$-tests. All analyses were run with logarithmically transformed data $[\log (x+1)]$.

\section{RESULTS}

\section{Small scale}

Water content of the sediments measured in March 1996 depended on topography (Fig. 2). Because of the low abundance of other organisms, it was only possible to analyze 2 species: Excirolana armata and Emerita brasiliensis for February and March 1996, and only E. armata for July 1996. In all cases patches of both species were observed (Fig. 3). A continuous belt of $E$. brasiliensis was found on every sampling date, and for E. armata in July 1996 (Fig. 3). Patchy distribution was statistically significant $(\mathrm{p}<0.05)$ on all occasions except in July for E: armata. Variogram curves showed a significant correlation with spatial lags (Fig. 4a to d). Although patches were observed in July 1996 (Fig. 3e) this trend was not evident in the variograms (Fig. 4e). The peaks of the patches were situated in the cusp bay although not exactly in the middle.

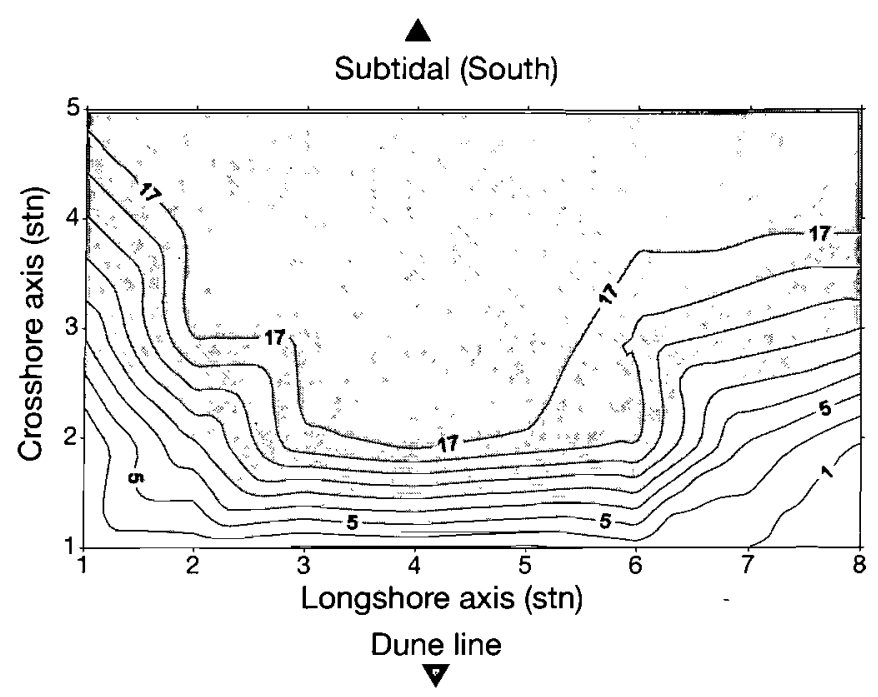

Fig. 2. Spatial patterns of sediment water content $(\%$ of wet weight) at small scale in 'Sur' beach, March 1996. Darker areas show zones of more water-saturated sediments 
On all occasions and for both species the patches evidenced an ellipsoidal shape (Fig. 3). This was also suggested by the fact that directional variograms separated by $90^{\circ}$ showed the existence of anisotropy: the slopes of different variograms tended to be different (compare variogram of Fig. $4 \mathrm{a}: 25^{\circ}$ with $115^{\circ}$; Fig. $4 \mathrm{C}$ : $25^{\circ}$ and $45^{\circ}$ with $115^{\circ}$ and $135^{\circ}$ respectively). In some diagrams a sill (asymptotic value of correlation) was reached at $L_{5}$ (Fig. $4 \mathrm{a}, \mathrm{C}, \mathrm{d}$ ); those values tended to be similar regardless of the slope of the variograms (except Fig. $4 \mathrm{a}, 25^{\circ}$ ). The differences in slopes tended to be associated with the range (lag distance at which the asymptotic value of correlation is reached), a common fact in patches of elliptic shape (Rossi et al. 1992). In general, patches were generally oriented with their main axis at an angle of 0 to $50^{\circ}$ with respect to the longshore axis.

We found more than 1 patch per cusp bay in all cases (Fig. 3). This is also shown in the variograms (Fig. 4 b,d: $135^{\circ}$; Fig. 4 b: $25^{\circ}$ ); at some specific directions correlograms had a 'hole effect structure', i.e. directional variograms had depressions beyond the sill, which are a consequence of the existence of separated zones with similar densities (Rossi et al. 1992). This means that more than 1 patch can be recognized.

\section{Meso scale}

Patterns at the scale of the stations

Abundance of Excirolana armata showed significant differences among levels, being higher in the medium and lower strata (Table 1). Mean abundance was higher in the bay than in the horn (Fig. 5a), but significant differences were found only in the middle level: there was a significant interaction Structure-Level (Table 1). The interactions Occasion-Transect, Occasion-Level and Occasion-Transect-Level were also significant (Table 1). Abundance peaked in the upper and middle levels between April and September (20 to 80 ind. $\mathrm{m}^{-2}$ ), and in the lower one between October and March (20 to 60 ind. $\mathrm{m}^{-2}$ ).

Significant differences in Excirolana braziliensis abundance were found in the interactions OccasionTransect and Occasion-Level, but not in Structure or in any other interaction related to it (Table 1). Although abundance peaked in the cusp horn (Fig. 5b), Struc-
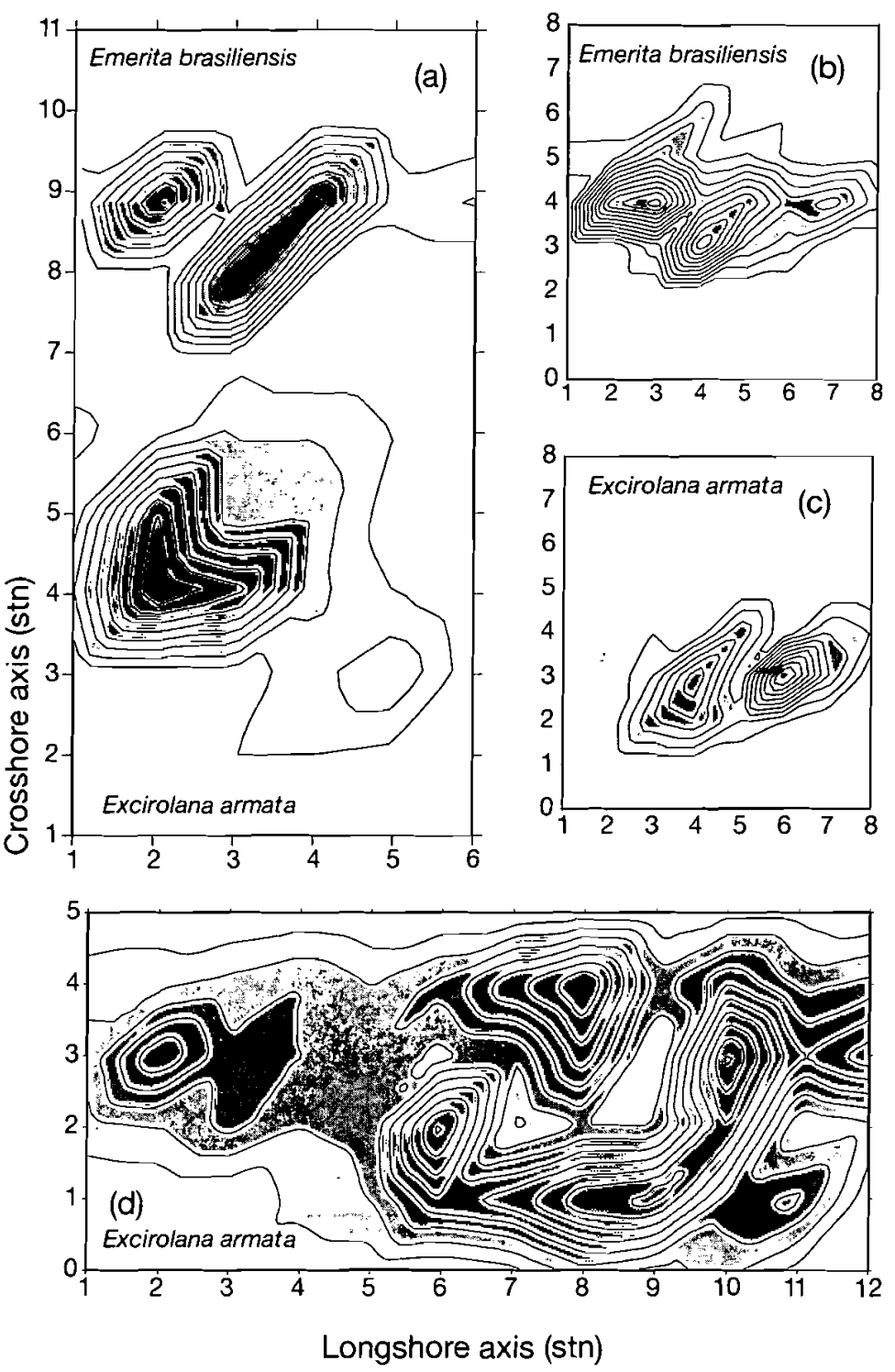

Fig. 3. Spatial distribution of infauna on 'Sur' beach at small scale. (a) February 1996, (b,c) March 1996, (d) July 1996. Darker areas show zones of higher individual densities. Lines joining points of equal abundance are set every 1 (c), 3 (a [Excirolana armata] and d), 6 (a [Emerita brasiliensis]) or 10 (b) individuals. The white areas represent zones without individuals and the darkest ones, zones equal or higher than 10 (c), 30 (a [E. armata] and d), 60 (a [E. brasiliensis]) and 120 (b) individuals

ture only was significant when the factor Transect was removed from the analysis (not shown). E. braziliensis changed the main level of occurrence with time; abundance peaked between June and September in the upper level ( 10 to 20 ind. $\mathrm{m}^{-2}$ ), and between December and May in the middle level (5 to 10 ind. $\mathrm{m}^{-2}$ ).

Emerita brasiliensis occurred in the middle and lower levels (Fig. 5c). Number of individuals varied seasonally, with maxima in March and May (150 to 300 ind. $\mathrm{m}^{-2}$ ) and minima from September to January. 
Table 1. Four-factor nested-ANOVA of repeated measures of mean abundance of 3 infaunal species at different sites (Structure, Transect, Level) and times (Occasions) of collection in a sandy beach. The factor Transect is nested in Structure; the repeated measures were done on the variable Occasion. For Emerita brasiliensis the upper beach levels was not considered in the model. Significant differences at $\mathrm{p}<0.05$ are given in bold. MSF, dfF and MSe, dfe: mean squares and degrees of freedoom of factors and errors respectively

\begin{tabular}{|c|c|c|c|c|c|c|c|c|c|c|c|c|c|c|c|c|}
\hline \multirow[t]{2}{*}{ Source } & \multicolumn{6}{|c|}{ Excirolana armata } & \multicolumn{4}{|c|}{ Excirolana braziliensis } & \multicolumn{6}{|c|}{ Emerita brasiliensis } \\
\hline & MSF & $\mathrm{dfF}$ & MSe & dfe & $F$ & $\mathrm{p}$ & MSF & MSe & $F$ & $\mathbf{p}$ & MSF & $\mathrm{dfF}$ & MSe & dfe & $F$ & $\mathrm{p}$ \\
\hline Structure (S) & 1.99 & 1 & 0.13 & 2 & 15.26 & 0.06 & 0.09 & 0.01 & 6.26 & 0.13 & 0.14 & 1 & 0.13 & 2 & 1.06 & 0.41 \\
\hline Transect $(\mathrm{T})$ & 0.13 & 2 & 0.14 & 88 & 0.92 & 0.40 & 0.01 & 0.02 & 0.75 & 0.47 & 0.12 & 2 & 0.09 & 60 & 1.39 & 0.26 \\
\hline Level (L) & 3.37 & 2 & 0.05 & 2 & 73.46 & $<0.001$ & 0.34 & 0.01 & 22.09 & $<0.01$ & 0.02 & 1 & 0.38 & 2 & 0.04 & 0.84 \\
\hline Occasion $(O)$ & 0.20 & 12 & 0.18 & 24 & 1.08 & 0.41 & 0.03 & 0.03 & 1.23 & 0.32 & 0.27 & 12 & 0.20 & 24 & 1.33 & 0.26 \\
\hline $\mathrm{S} \times \mathrm{L}$ & 0.44 & 2 & 0.05 & 4 & 9.54 & $<0.05$ & 0.02 & 0.01 & 1.45 & 0.33 & 0.01 & 1 & 0.38 & 2 & 0.02 & 0.90 \\
\hline $\mathrm{S} \times \mathrm{O}$ & 0.13 & 12 & 0.18 & 24 & 0.70 & 0.73 & 0.02 & 0.03 & 0.80 & 0.64 & 0.16 & 12 & 0.20 & 24 & 0.83 & 0.61 \\
\hline $\mathrm{T} \times \mathrm{L}$ & 0.04 & 4 & 0.14 & 88 & 0.32 & 0.86 & 0.01 & 0.02 & 0.79 & 0.53 & 0.43 & 2 & 0.07 & 60 & 5.81 & $<0.01$ \\
\hline $\mathrm{T} \times \mathrm{O}$ & 0.18 & 24 & 0.05 & 1056 & 3.31 & $<10^{-5}$ & 0.03 & 0.01 & 2.30 & $<0.001$ & 0.20 & 24 & 0.07 & 720 & 2.97 & $<10^{-5}$ \\
\hline $\mathrm{L} \times \mathrm{O}$ & 0.38 & 24 & 0.21 & 48 & 1.87 & $<0.05$ & 0.06 & 0.02 & 2.51 & $<0.01$ & 0.20 & 12 & 0.13 & 24 & 1.60 & 0.16 \\
\hline $\mathrm{S} \times \mathrm{L} \times \mathrm{O}$ & 0.17 & 24 & 0.20 & 48 & 0.83 & 0.67 & 0.01 & 0.0 & 0.79 & 0.73 & 0.13 & 12 & 0.13 & 24 & 1.03 & 0.44 \\
\hline $\mathrm{T} \times \mathrm{L} \times \mathrm{O}$ & 0.20 & 48 & 0.05 & 1056 & 3.66 & $<10^{-5}$ & 0.02 & 0.01 & 2.00 & 0.001 & 0.12 & 24 & 0.07 & 720 & 1.88 & $<0.01$ \\
\hline
\end{tabular}
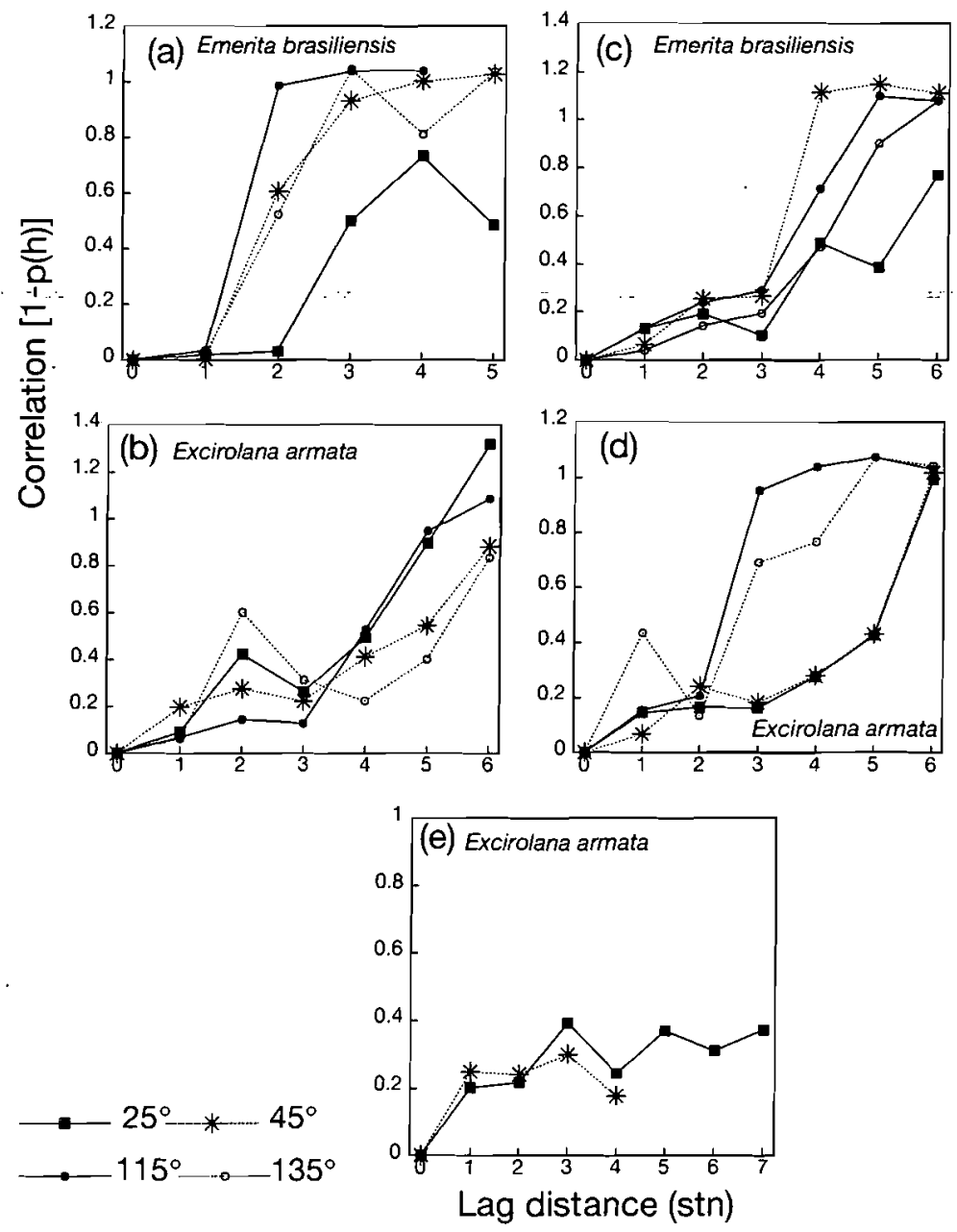

Fig. 4. Spatial distribution of infauna at small scale on 'Sur' beach. (a,b) February 1996; (c,d) March 1996; (e) July 1996
Although abundance peaked in the cusp bay (Fig. 5c), there was no significant effect of Structure (Table 1).

\section{Pattern at the scale of the transects}

When abundance was pooled for transects all species showed significant differences related to Structure (Table 2). The abundance of Excirolana armata and Emerita brasiliensis was higher at the bay than at the horn, while Excirolana braziliensis showed the opposite pattern. For E. armata there was a significant effect of Position and Position-Occasion interaction: abundance was higher on the east side (ca 20 and 50 ind. transect ${ }^{-1}$ in the horn and bay, respectively) than on the west (10 and 40 ind. transect ${ }^{-1}$ in horn and bay respectively), especially from September to January. For E. brasiliensis there was a significant effect of Occasion (Table 2). E. braziliensis showed a significant effect of Occasion ( $p<$ 0.05 ) only when we pooled all interactions with the error (not shown).

\section{Cross-shore species distribution}

The ACF of Excirolana armata was well adjusted by our model (Fig. 6a), and cusp bay and horn curves had similar slopes $(p>0.10)$. Our model also adjusted well for Excirolana braziliensis (Fig. 6b) but the curves for bay 


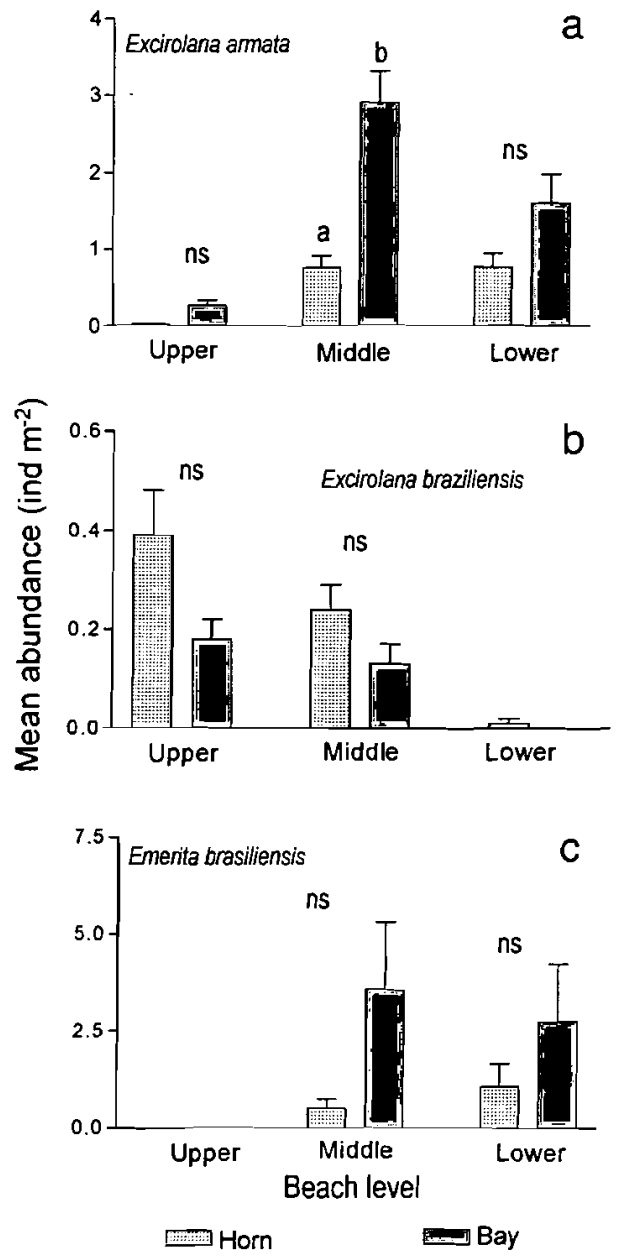

Fig. 5. Mean density of 3 infaunal species at meso scale, scale of the stations, depending on level and cusp topography on 'Sur' beach. Error bars: $\mathrm{SE}_{\text {; }}$ different letters above columns: significant differences $(p<0.05)$ among treatment combinations (Tukey test); ns: not significant differences

and horn were different: there was a stronger loss of correlation between $L_{0}$ (for ACFS $\mathrm{r}=1$ at $L_{0}$ ) and $L_{1}$ at the cusp horn than at the bay, and the slope of the
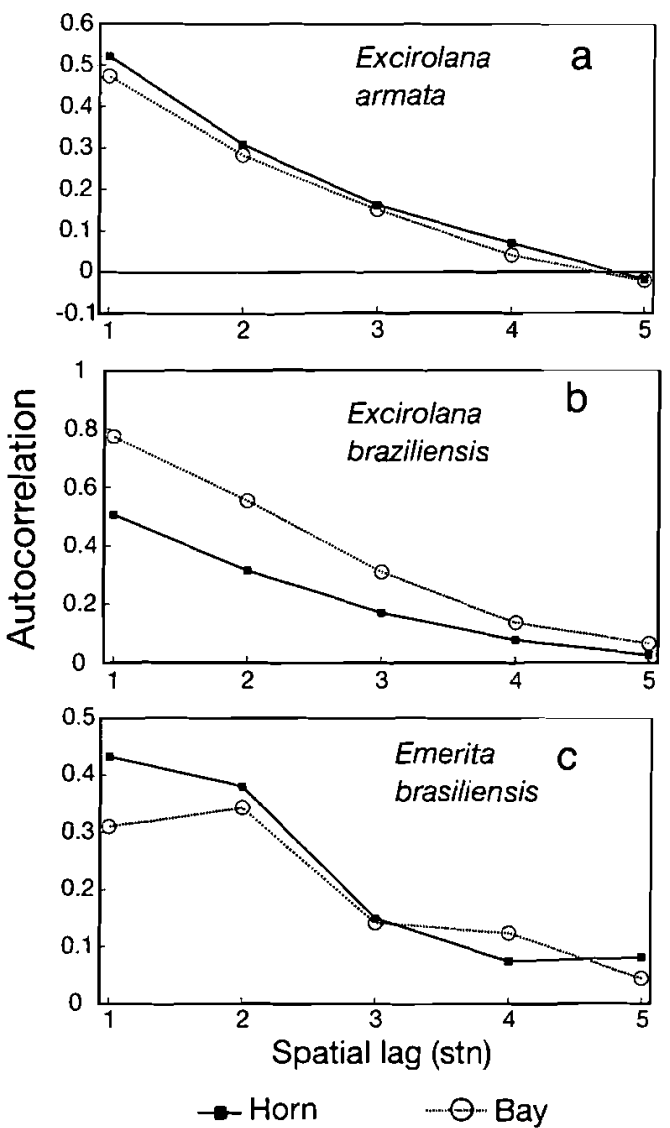

Fig. 6. Spatial autocorrelation of cross-shore distribution of 3 infaunal species at meso scale on 'Sur' beach

curve was steeper than at the horn $(p<0.01)$. The distribution was therefore more aggregated at the horn. For Emerita brasiliensis a potential model did not fit well (Fig. 6c): the ACF decreased in a complex way. For the cusp bay there was an increment in the autocorrelation between $L_{1}$ and $L_{2}$ suggesting the existence of a bimodal distribution. In the horn, the autocorrelation always decreased as lag increased but the

Table 2. Three-way ANOVAs without replication performed on abundance per line transect in 3 infaunal species. The factors were Occasion (O) with 13 levels (months), Structure (S) with 2 levels (cusp horn and bay) and Position (P) with 2 levels (East and West). Significant differences at $p<0.05$ are given in bold

\begin{tabular}{|c|c|c|c|c|c|c|c|c|c|c|c|c|}
\hline \multirow[t]{2}{*}{ Source } & \multicolumn{4}{|c|}{ Excirolana armata } & \multicolumn{4}{|c|}{ Excirolana braziliensis } & \multicolumn{4}{|c|}{ Emerita brasiliensis } \\
\hline & MS & df & $F$ & $\mathrm{p}$ & MS & df & $F$ & $\mathrm{p}$ & MS & $d \mathbf{f}$ & $F$ & $\mathrm{p}$ \\
\hline $\mathrm{O}$ & 1.44 & 12 & 2.52 & 0.06 & 1.49 & 12 & 2.66 & 0.05 & 9.09 & 12 & 10.07 & $<10^{-3}$ \\
\hline $\mathrm{S}$ & 22.04 & 1 & 38.66 & $<10^{-3}$ & 4.44 & 1 & 7.93 & 0.02 & 6.95 & 1 & 7.70 & 0.02 \\
\hline $\mathrm{P}$ & 5.14 & 1 & 9.02 & 0.01 & 0.43 & 1 & 0.77 & 0.40 & 0.94 & 1 & 1.04 & 0.33 \\
\hline $\mathrm{O} \times \mathrm{S}$ & 0.90 & 12 & 1.59 & 0.22 & 0.59 & 12 & 1.06 & 0.46 & 1.85 & 12 & 2.05 & 0.11 \\
\hline $\mathrm{O} \times \mathrm{P}$ & 1.84 & 12 & 3.22 & 0.03 & 1.01 & 12 & 1.80 & 0.16 & 0.59 & 12 & 0.65 & 0.77 \\
\hline$S \times P$ & 0.26 & 1 & 0.45 & 0.51 & 0.60 & 1 & 1.08 & 0.32 & 0.16 & 1 & 0.18 & 0.68 \\
\hline Error & 0.57 & 12 & & & 0.56 & 12 & & & 0.90 & 12 & & \\
\hline
\end{tabular}




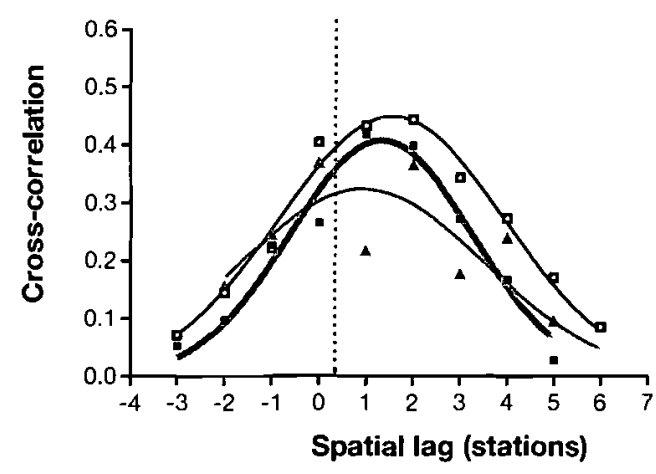

- E. armata $\rightarrow$ Excirolana braziliensis $*$ Emerita brasiliensis

Fig. 7. Spatial cross-correlation of cross-shore distribution for 3 infaunal species at meso scale. Points show cross-correlation values; lines show non-linear adjusting of a Gaussian function to each species

curve evidenced an inflexion point: the highest decrement in autocorrelation occurred between $L_{0}$ and $L_{1}$, and $L_{2}$ and $L_{3 i}$ however between $L_{1}$ and $L_{2}$ the autocorrelation function was almost flat (Fig. 6c).

A Gaussian function was adjusted to the $\mathrm{CCF}$ with determination coefficients of $0.958,0.979$ and 0.714 for Excirolana armata, Excirolana braziliensis and Emerita brasiliensis respectively ( $\mathrm{df}=6,7$ and 6) (Fig. 7). In the same order, the function peaked at $L=1.32,1.55$ and 0.93 , which meant that all species were distributed nearer to the dune line in the cusp bay than in the horn. Only for Excirolana species were they significatively different from $L_{0}$ (CI $99 \%$ : 0.876 to 1.771 for $E$. armata; 1.243 to 1.853 for E. braziliensis; -0.793 to 2.664 for E. brasiliensis).

\section{Large scale}

In the upper beach level, sediment water content increased from low $(5 \%)$ to high $(15 \%)$ values in the westward direction (Fig. 8a). This increment, at about $1100 \mathrm{~m}$ from the Cabo Polonio, was due to the appearance of shallow pools of freshwater coming from the dunes. There were also longshore changes in beach topography. At the east sector the upper level of the sampled area ( 0 to $1100 \mathrm{~m}$ in Fig. 8) was flat or slightly convex, while at the west sector (1100 to $3000 \mathrm{~m}$ ) it was concave. In the middle beach level the differences in water content between cusp bays and horns were more evident (ca 5 and $18 \%$ respectively). There were no changes in water content of the sediment of the lower level along the longshore axis, or in relation to the horn-bay topography (Fig. 8c) since it was always saturated (ca 18\%). The longshore changes in beach topography were associated with changes in the dune characteristics. To the east the dunes had a smooth

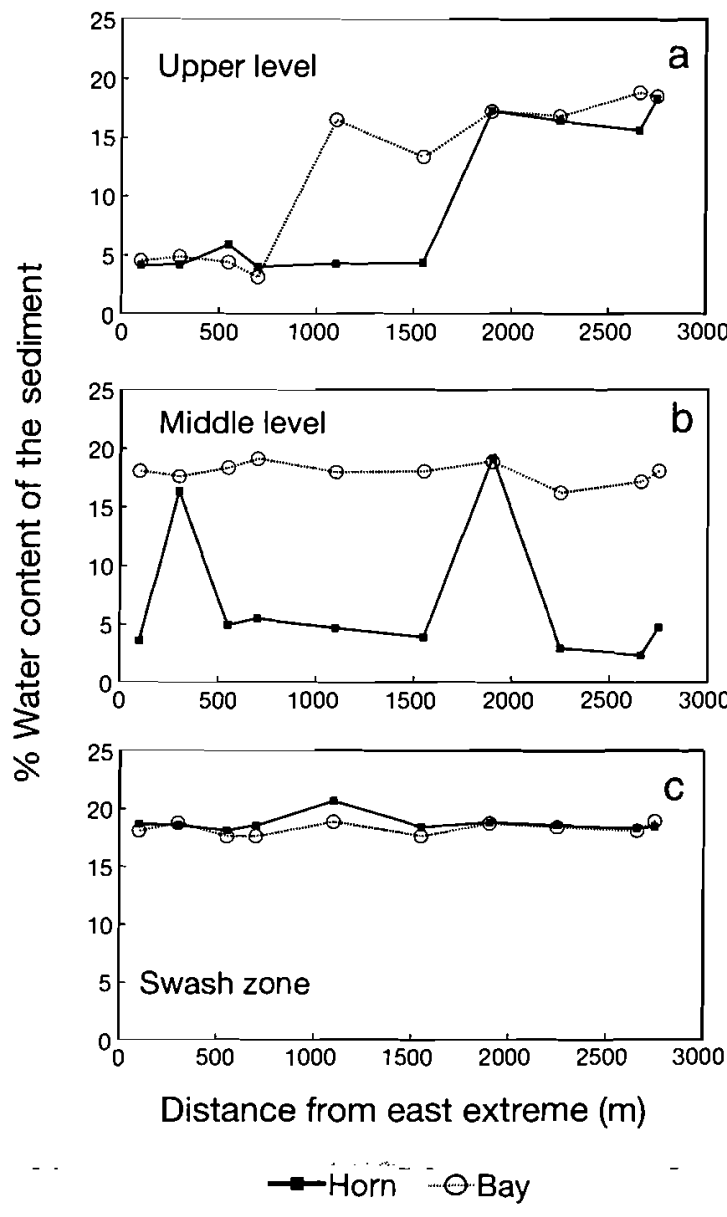

Fig. 8. Longshore distribution of sediment water content (\% wet weight) at large scale on 'Sur' beach

slope and lacked vegetation. Those of the west area had steeper slopes and were stabilized with grasses that occasionally invaded the upper beach level.

Towards the west, besides Excirolana armata, Excirolana braziliensis and Emerita brasiliensis, several species of insects occurred (Fig. 9). Only for E. armata were there significant differences in abundance related to the cusp horn-bay system (Table 3 for $E$. armata; for other species $\mathrm{p}>0.05$ : paired $t$-test). Abundance was higher in the cusp bay than in the horn (Fig. 9a,c). In August, there was an important longshore variability in abundance; in February the high $E$. armata abundance related to the cusp bays was more clearly seen at the east side of the beach. In August, abundance of $E$. braziliensis peaked on the east side of the sampled area. In February, we found high insect abundance toward the west side (Fig. 9d). There were larval and adult phases of several species of Coleoptera and Diptera (Table 4) inhabiting the upper beach level. The most abundant groups were carabid coleopters and ephydrid larvae (Table 4). The adult 

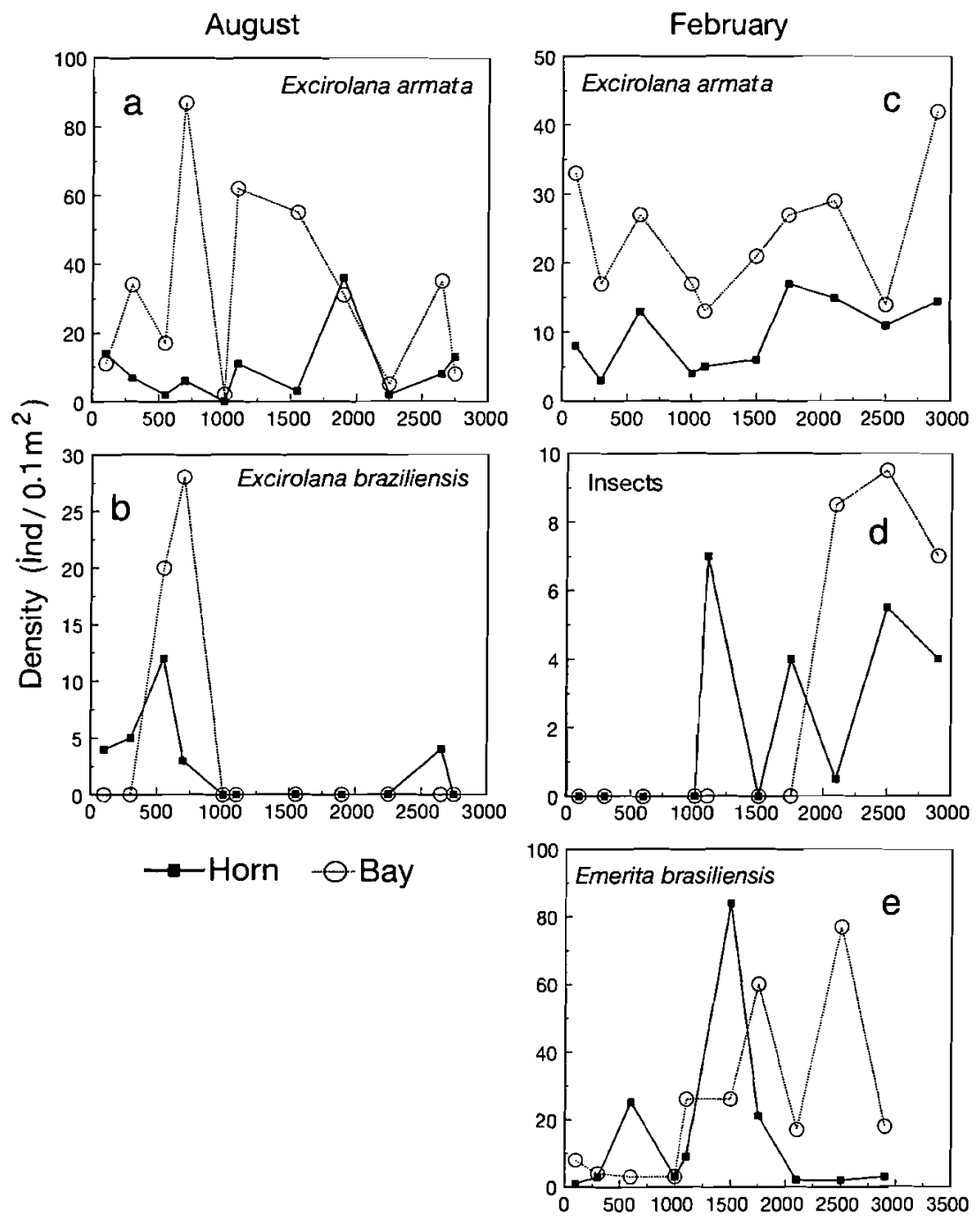

Distance from east extreme $(\mathrm{m})$

Fig. 9. Longshore distribution of 3 infaunal species and insects (adult and larval phases pooled) at large scale on 'Sur' beach. See Table 3 and text for results of statistical tests

Table 3. Repeated measures ANOVA to study the effect of longshore topography on abundance of Excirolana armata at a large scale. In Structure, Level and Occasion, $\mathrm{df}=\mathbf{1}_{\text {; }}$ in Error, df error $=18$. Significant differences at $p<0.05$ are given in bold

\begin{tabular}{|lcccr|}
\hline & MS factors & MS error & \multicolumn{1}{c|}{$F$} & \multicolumn{1}{c|}{$\mathbf{p}$} \\
\hline Occasion (O) & 0.06 & 0.31 & 0.17 & 0.68 \\
Level (L) & 0.83 & 0.32 & 2.55 & 0.12 \\
Structure (S) & 1.14 & 0.11 & 10.01 & $<\mathbf{0 . 0 1}$ \\
$\mathrm{O} \times \mathrm{L}$ & 4.64 & 0.32 & 14.21 & $<\mathbf{0 . 0 1}$ \\
$\mathrm{O} \times \mathrm{S}$ & 0.13 & 0.11 & 1.15 & 0.29 \\
$\mathrm{~L} \times \mathrm{S}$ & 0.36 & 0.14 & 2.53 & 0.13 \\
$\mathrm{O} \times \mathrm{L} \times \mathrm{S}$ & 0.0005 & 0.14 & 0.003 & 0.95 \\
\hline
\end{tabular}

forms of insects and all but ephydrid larvae were buried in the water-saturated sand exposed to the air. Ephydrid larvae were found buried in the bottom sediments of the pools. Also in February, $E$. brasiliensis showed high variability in abundance, but it was not related to cusp topography (Fig. 9e).

\section{DISCUSSION}

\section{Small-scale distribution patterns}

The scavenger isopod Excirolana armata and the filter feeder Emerita brasiliensis showed an aggregated distribution with maximum abundance in the cusp bay. Patchiness of infauna in cusp systems has already been studied by Dye et al. (1981), McLachlan \& Hesp (1984) and Donn et al. (1986). They found that filter feeders were more common in the cusp bays while scavengers occurred preferentially in the horns. McLachlan \& Hesp (1984) proposed an active site selection strategy as a possible explanation for such patterns. Filter feeders would select bays because there is a maximum feeding time and lower swash speeds, while scavengers would select the horns, where food particles may concentrate due to rapid water infiltration. They considered passive transport as a factor influencing such patchiness. The active site selection hypothesis fits the distribution pattern found for $E$. braziliensis but not that found for E. armata. Two facts must be considered to explain the differences between McLachlan \& Hesp's (1984) results and ours: (1) the 2 studies were made in morphodynamically different beaches, with different filtration rates due to grain size (McLachlan 1982); and (2) the scavengers considered in our study displayed a distinct type of movement. While in reflective beaches most carrion is deposited in the upper swash, in our intermediate-dissipative beach, with finer sands (Giménez \& Yanicelli 1997), lower water filtration rates would let the waves move carrion up and down on the bays. The scavengers considered by McLachlan \& Hesp (1984) were downshore migrants as defined by Naylor \& Rejeki (1996), i.e. they moved on the beach face rather independently of the swash action (autonomous active movement; Giménez \& Yannicelli 1997). 
Table 4. Main taxonomic groups, life phase, habitat occupied and abundance of insects that occurred in 10 sampling units $\left(0.1 \mathrm{~m}^{2}\right.$ each) of the west sector $(1100$ to $3000 \mathrm{~m})$ of the area sampled in the large-scale sampling. All individuals were found in the upper beach level. nd: unidentified individuals

\begin{tabular}{|llcc|}
\hline Taxonomic group & Life phase & Bay & Horn \\
\hline Coleoptera & & & \\
Staphilinidae & Adults & & 1 \\
Carabidae & Adults & 42 & 11 \\
Tenebrionidae & Adults & & 2 \\
nd & Adults & 1 & 1 \\
nd & Adults & 1 & 1 \\
nd & Larva & 1 & \\
Diptera & & & \\
Ephydridae & Adults & 1 & \\
Chironomidae & Larvae & 7 & 11 \\
nd & Larvae & 3 & 6 \\
nd & Adults & 1 & 1 \\
nd & Pupae & 1 & 1 \\
& Larvae & 4 & 1 \\
\hline
\end{tabular}

E. armata is however a 'swash rider', it does not crawl on the beach face, but swims when the sea level rises (swash-mediated active movement). As for filter feeders, it would be advantageous for $E$. armata to occur on cusp bays, where the swash is wider and the waves slower. In dissipative beaches, where E. armata occurs, a possible balance between current speed and swimming ability would determine distribution.

Additionally, our beach was inhabited by another scavenger isopod, Excirolana braziliensis, which occupies the upper swash and the cusp horns. E. braziliensis is also a 'swash rider' and is of a size similar to $E$. armata. If currents alone were responsible for its distribution they would occur largely in the same area. Whatever the reason for the segregation, interspecific competition (Defeo et al. 1997) or differences in food searching strategies (Yannicelli 1998), it must involve some control on their movements within the restrictions imposed by topography and swash dynamics.

An analysis of patch shapes showed the effect of hydrodynamic action on organism distribution. In Emerita brasiliensis and Excirolana armata, the shape of the patches was ellipsoidal, oriented obliquely to the longshore axis of the beach with the shortest axis parallel to the direction of the upswash movement. This may occur because the upswash enters cusp bays at an oblique angle. The upswash tends to carry organisms landwards, producing a contraction of the patch in that direction. Later, as the back swash leaves the bay at an angle perpendicular to the previous upswash, some organisms could be carried downward, thus extending the patch and giving it an ellipsoidal shape. This process would produce the same individual movement suggested by Dillery \& Knapp (1969): while patches remain rather static, individuals may move between patches in the direction of the longshore currents.

In our study and that of McLachlan \& Hesp (1984), there was more than 1 patch within a single cusp bay. In the case of the latter study, the presence of multiple patches might reflect the symmetrical shape of the cusp system: the patches were situated to the sides of the cross-shore axis that passes through the center of the bay. This pattern was not clear in our case: patches were situated rather close to each other, and in July 1996 (Fig. 3d: Excirolana armata) we found more than 2 patches. They could reflect the existence of microtopographic structures within the cusp bay, or they could be a consequence of a size-sorting process carried out by the swash currents, intraspecific competition (de Alava \& Defeo 1991, Defeo et al. 1997) or the unstable nature of the cusp structures (see Masselink et al. 1997 for beach cusp morphodynamics).

\section{Meso-scale distribution patterns}

To analyze patterns of infaunal distribution at our meso scale we used different approaches taking (1) stations and (2) whole transects as samples of a stratified area. Both approaches have different grain (sensu Wiens 1989), produced different results and must be evaluated taking into account the results obtained at the small-scale sampling.

The sampling at the scale of the stations showed that only for Excirolana armata were there differences in distribution related to the topography and they depended on the beach level (Fig. 5). Considering the results of the small-scale sampling we could expect significant differences in Emerita brasiliensis spatial distribution. This result could be a consequence of the existence of (1) small-scale aggregations and/or (2) a spatio-temporal-dependent aggregation process. In nature organisms usually show aggregated distribution, but statistical analyses assume that at the scale of the replications they are randomly distributed. If this assumption is violated, the computed test statistics are biased (Legendre 1993). Small-scale, non-random variability has been documented for Excirolana armata and Emerita brasiliensis by our small-scale sampling (Figs. $3 \& 4$ ), and for all species by the autocorrelation functions (Fig. 6). This variability may have biased estimations of statistics in the ANOVA; regardless of the differences in mean values (Fig. 5), they were significant only for E. armata. A second possibility is that the effect of structure depends on beach level and sampling occasion. In the upper and lower beach levels there was almost no topographic variability. These levels are occupied by Excirolana braziliensis and E. 
brasiliensis respectively, so no differences in abundance related to the cusp topography should be expected. Additionally, species distribution on the cross-shore axis also varies with time (Giménez \& Yanicelli 1997). Occasionally, E. brasiliensis or E. braziliensis are most abundant in the middle level, where the effects of structure on abundance should be stronger. This possibility would lead to a significant interaction among Structure, Occasion and Level, which we did not observe (Table 1).

In order to overcome the problems of the previous analysis we asked whether total abundance per transect was affected by topographic structure. We pooled all data from each transect, eliminating all the variability at the scale of the stations, and ran new statistical tests with the analysis at the scale of the transects (transects instead of stations as replicates). With this procedure we found significant differences in abundance related to the longshore topographic structure for all species (Table 2). For Excirolana armata and E. brasiliensis, the differences reflected the pattern found at our small-scale sampling, with maximum abundances found in the cusp bay. Additionally, the analysis showed (1) significant longshore variability in abundance not related with the cusp topography for $E$. armata; (2) a significant effect of Occasion for $E$. brasiliensis; and (3) significant differences related to the cusp system for Excirolana braziliensis. For $E$. armata, the significant longshore variability in abundance, not related with the cusp-bay topography, could be associated to variability in the extension and height of cusp bays and horns. Such topographic variability is caused by processes operating at least at the scale of the sampled area, like swash and wind dynamics.

These results suggest that cross-shore variability at the scale of the stations could have biased the statistical test, despite the division of the beach into levels. Only when this variability was eliminated did the patchiness related to the bay-horn cusp system became evident. Scale-dependent results in infaunal distribution at scales similar to those discussed here were found in another Uruguayan sandy beach (Defeo 1996a). From the above we can conclude that (1) sampling at the scale of the transects is a useful approach to detect longshore variability in infaunal distribution related to beach topography; and (2) infaunal abundance was related to the cusp system.

Autocorrelations showed that the degree of patchiness changed with the cusp topography (Fig. 6). For Excirolana armata and especially for Emerita brasiliensis the values decreased more in the bay than in the horn. For Excirolana braziliensis the sharpest decline was in the cusp horn, where it was most commonly found. This suggests that the degree of patchiness would depend more on animal density or habitat quality than on cusp topography; if cusp topography were the main factor, we would have expected the opposite pattern to that we found. In this scenario, both $E$. armata and $E$. brasiliensis should have been more patchy in the horn, where physical gradients in the swash zone are stronger. The degree of patchiness for $E$. braziliensis should have been weaker in the horn, where physical gradients of the upper beach levels are not so strong. For E. armata and E. brasiliensis this is in accordance with the small-scale sampling; there was not a single big patch but rather 2 or more small patches with sharp limits. In the case of $E$. brasiliensis this is also suggested by the increase in the autocorrelation at $L_{2}$ which may be interpreted as evidence of more than 1 peak of abundance (Fig. 6c).

Cross-correlation analysis showed that for Excirolana armata and Excirolana braziliensis the peak of the distribution in the cusp horn and bay were spatially lagged (Fig. 7). Both species tended to occur nearer the dune line in the cusp bays than in the horns. We did not find the same pattern for Emerita brasiliensis, which could be due to (1) the species occurring in the lowest beach levels, where the cusp topography is smoother, and/or (2) the bimodal distribution found in the bay affecting our methods and tests. Both hypotheses are not mutually exclusive but we are inclined to agree with the second hypothesis because (1) our small-scale sampling suggests that in the lower level the cusp topography is sufficient to produce patches (Fig. 3a,b), and (2) the cross-correlation peak at $L_{2}$ (Fig. 6c) evidenced that $E$. brasiliensis was distributed bimodally in the bays.

\section{Large-scale distribution patterns}

Physical gradients and infaunal distribution at large scale (extent of $3000 \mathrm{~m}$ ) did not match the expected pattern obtained from the extrapolation of those at small and meso scales. We found a longshore gradient in water content of the sediment and species distribution in the beach (Figs. 8 \& 9), and also in the morphological and vegetational characteristics of the dunes. Only the distribution of Excirolana armata was related to the cusp system (Fig. 9) in the same way that was found at smaller scales. In August, Excirolana braziliensis peaked at the east side of the area, where sediments in the upper beach levels were dryer (Fig. 9b). Insects followed the opposite pattern: they peaked in sites with water-saturated sediments, usually associated with freshwater pools in the upper beach level (Fig. 9d). The distribution of both groups seemed to be dependent on the longshore variability in sediment water content (Fig. 8). However, the abovementioned 
spatial distribution was found on 1 sampling occasion only. Additional data show that the west sector is occupied by insects during summer and that $E$. braziliensis abundance is highly variable (authors' unpubl. data). E. armata and Emerita brasiliensis showed large-scale variability not associated with any measured environmental gradient.

The large-scale distribution of both insects and Excirolana braziliensis in Cabo Polonio is related to sediment water content variability along the $3000 \mathrm{~m}$ studied. Insects occur on some sandy beaches (Doyen 1976, Chelazzi et al. 1983, Gianuca 1983, Griffiths et al. 1983, Defeo et al. 1992, Fallaci et al. 1994). They are usually associated with decaying seaweeds (Moore \& Legner 1976, Griffiths et al. 1983, Inglis 1989, Colombini et al. 1994) and moist sands (Craig 1970, Simpson 1976), where they find food, shelter and are protected from dessication. The upper beach levels in the west sector of the study area had sediments saturated by freshwater draining from the dune system and shallow pools covered with microalgae, providing an adequate habitat for the establishment of insects. On the contrary, freshwater-saturated sediment may impose a high physiological stress on $E$. braziliensis. It has been experimentally shown that even though $E$. braziliensis tolerates a wide range of salinity conditions survivorship largely decreases below 10 psu (Dexter 1977). The appearance of freshwater pools towards the west sector of the large-scale sampled area correlates with the presence of conspicuous vegetation on the adjacent dunes, and some evidence of erosion (lack of foredunes and dunes with steep slopes showing uncovered plant roots). Piñeiro \& Panario (1993), studying patterns of sand transport in Cabo Polonio, concluded that a forested fringe set about $2 \mathrm{~km}$ west of Cabo Polonio has modified patterns of sand transport by the wind, causing the inactivation of coastal dunes, the establishment of vegetation, and the erosion of the entire beach arc. It has been documented that vegetation traps sand, and therefore modifies patterns of sand transport, favoring erosion (see review in Goldsmith 1985, Brown \& McLachlan 1990). If modification of sand transport is operating on the beach producing erosion, the west sector must be under higher erosion than the east one. So, it is possible that large-scale patterns of sand transport and erosion could be affecting the intertidal community structure.

We also found large-scale variability for Emerita brasiliensis and also Excirolana armata, but not related to the longshore patterns discussed in the previous paragraphs. The plots of Fig. 9 suggest the existence of several aggregations at a scale of hundreds of meters. Here we define aggregations sensu McArdle \& Blackwell (1989). Aggregations of E. brasiliensis and $E$. armata resemble those found by McArdle \& Blackwell
(1989) for the mollusc Chione stutchburyi, by Jaramillo (1994) for the mollusc Mesodesma donacium or by Dugan \& Hubbard (1996) for the sand crab. Emerita analoga. They could be a consequence of spatial variations in recruitment, recruit mortality and post-settlement dispersion as discussed by Donn (1987), Dugan \& Hubbard (1996) and Defeo (1996b). Those processes could be associated to beach cusps and/or water circulation variability.

\section{Multiscale patterns}

Our study showed that infaunal distribution patterns on sandy beaches are scale dependent. This result agrees with many others found in very different ecological systems (see Wiens et al. 1986, Wiens 1989, Levin 1992, Underwood \& Chapman 1996, Thrush et al. 1997a) and show the effects of spatial pseudoreplication discussed by Hurlbert (1984). In contrast to that found by Dauer \& Simon (1975), longshore variation in infaunal abundance can be very important, even when transects are used as sampling design. At a small scale, spatial distribution consisted of patches or aggregations of Excirolana armata and Emerita brasiliensis that temporally change their position and number. At meso scale the spatial distribution consisted of belts of E. armata, Excirolana braziliensis and E. brasiliensis that (1) temporally changed their position in the cross- shore axis (Giménez \& Yannicelli 1997), and (2) were composed of aggregations associated to the beach longshore topography. At a large scale, the spatial distribution of this sandy beach macroinfauna consisted of belts of different extensions depending on the species. For $E$. armata and E. brasiliensis, the belts were continuous but showed aggregations at the scale of hundreds of meters. For $E$. braziliensis and insect species the belts were interrupted and took the shape of patches of hundreds to thousands of meters of extension.

On sandy beaches the processes responsible for the patterns found at different spatial scales may differ from those producing similar patterns on rocky shores or sandflats. Present evidence, especially from rocky shores, suggest that small-scale patterns may be highly influenced by biotic interactions such as competition (Connell 1961), predation (Paine 1974), or animal behavior (Underwood \& Chapman 1996). Large-scale patterns would be influenced by physical factors, such as water circulation, which affect supply of larvae (Roughgarden et al. 1988) and nutrients (Menge et al. 1997). Spatial patterns in soft-bottom communities seem to be determined by life history (site selection by larvae, feeding and motility modes), physical (sediment characteristics) and biological (competition, pre- 
dation) factors (reviewed by Thrush 1992). Recent work on sandflats has shown that (1) different processes are operating at different spatial scales and (2) processes operating at small scales can influence large-scale patterns (Thrush et al. 1997b). At scales of meters larva-adult interactions seem to be an important factor producing patches of infauna (Turner et al. 1997). At larger scales (hundreds of meters), spatial distribution was more related to physical factors (topography, ebb and flood-shear stress, wind stress) that may influence post-larval dispersal (Legendre et al. 1997). Small-scale patterns of distribution may be structured by biotic and abiotic processes, but largescale patterns may be primarily affected by abiotic processes (Barry \& Dayton 1991).

Classic theory suggests that sandy beaches are communities that are physically structured (McLachlan 1988, McLachlan et al. 1993), and observed patterns of distribution are the consequence of individual population response to physical factors (grain size, slope, swash climate, sediment moisture). However, it was suggested recently that small-scale patterns of distribution could be affected by biotic processes such as interspecific competition and larva-adult interactions (Defeo 1996b) as in sandflats (see Turner et al. 1997). We suggest that in Cabo Polonio small- and meso-scale patterns of distribution are affected by transport of individuals and food, which would depend in part on topographic features of the beach, such as cusps.

Large-scale distribution patterns in sandy beach communities may be affected by larval supply, gradients of production (Defeo 1996b), as in rocky shores and soft-sediment subtidal (Josefson 1987), and postsettlement dispersal (Donn 1987). Those processes could have affected the large-scale patterns of abundance for Emerita brasiliensis and Excirolana armata. At a large scale, our work suggests the existence of an additional process characteristic of sandy beaches: the high transport rate of substrate by waves, currents and wind. Our results suggests that at large scales sandy beach communities are partially structured by patterns of sand transport that link the intertidal (the sandy beach) and the terrestrial environment (the dune ecosystem). Hence, it is possible to identify 2 groups of processes affecting infaunal distribution at large scale: (1) those that link the beach and the dune habitat (sand transport by the wind), and (2) those linking the pelagic and the benthic environments (water circulation dynamics, and larval and food supply).

In summary our data show that on the longshore axis the community structure of sandy beaches is scale dependent, and suggest that different processes could be operating at different spatial/temporal scales. Future experimental approaches combined with new sampling designs are needed to answer the main ques- tions that evolve from this work: (1) How persistent are large-scale distribution patterns? (2) What are the factors causing small-scale patches? and (3) How and to what extent is sandy beach macroinfauna affected by sand transport?

Acknowledgements. This work could not have been done without the help from our friends: E. Peluffo and 'Piava' kindly provided us with housing in Cabo Polonio. J. Sellanes, L. Quintana, L. Martínez, P. Muniz, G. Torres and, P. Elola helped with the sampling. Dr O. Defeo and Dr D. Calliari kindly reviewed and commented earlier versions of the manuscript. Financial support was given by the 'Comisión Sectorial de lnvestigación Científica' (CSIC), Universidad de la República, Uruguay.

\section{LITERATURE CITED}

Aberg P, Pavia H (1997) Temporal and multiscale spatial variation in juvenile and adult abundance of the brown algae Ascophyllum nodosum. Mar Ecol Prog Ser 158:111-119

Barry J, Dayton P (1991) Physical heterogeneity and the organization of marine communities. In: Kolasa J, Pickett $S$ (eds) Ecological heterogeneity. Springer-Verlag, Berlin, p 270-320

Brazeiro A, Defeo O (1996) Macroinfauna zonation in microtidal sandy beaches: is it possible to identify patterns in such a variable environment? Estuar Coast Shelf Sci 42 : 523-536

Brown A, McLachlan A (1990) Ecology of sandy shores. Elsevier, Amsterdam

Chelazzi G, Chelazzi L, Focardi S (1983) Dynamic zonation of staphylinoid beetles (Coleoptera: Staphylinoidea) on a sandy beach in east Africa. In: McLachlan A, Erasmus T (eds) Sandy beaches as ecosystems. Junk, The Hague, p 405-412

Colombini I, Chelazzi L, Fallaci M, Palesse L (1994) Zonation and surface activity of some tenebrionid beetles living on a Mediterranean sandy shore. J Arid Environ 28:215-230

Connell J (1961) The influence of intraspecific competition and other factors on the distribution of the barnacle Chthamalus stellatus. Ecology 42:710-722

Connell J, Hughes $\mathrm{H}$, Wallace C (1997) A 30-year study of coral abundance, recruitment, and disturbance at several scales in space and time. Ecol Monogr 67:461-488

Craig P (1970) The behavior and distribution of the intertidal sand beetle Thinopinus pictus (Coleoptera: Staphylinidae). Ecology 51:1012-1017

Dauer D, Simon J (1975) Lateral or along-shore distribution of the polychaetous annelids of an intertidal, sandy habitat. Mar Biol 31:363-370

de Alava A, Defeo O (1991) Distributional patterns and population dynamics of Excirolana armata (Isopoda: Cirolanidae) in a Uruguayan sandy beach. Estuar Coast Shelf Sci 33:433-444

Defeo O (1993) The effect of spatial scales in population dynamics and modeling of sedentary fisheries: the yellow clam Mesodesma mactroides of an Uruguayan exposed sandy beach. PhD thesis, CINVESTAV-IPN, Mérida

Defeo O (1996a) Experimental management of an exploited sandy beach bivalve population. Rev Chil Hist Nat 69: $605-614$

Defeo O (1996b) Recruitment variability in sandy beach macroinfauna: much to learn yet. Rev Chil Hist Nat 69: $615-630$ 
Defeo O, de Alava A (1995) Effects of human activities on long-term trends in sandy beach populations: the wedge clam Donax hanleyanus in Uruguay. Mar Ecol Prog Ser 123:73-82

Defeo O, Jaramillo E, Lyonnet A (1992) Community structure and intertidal zonation of the macroinfauna on the Atlantic coast of Uruguay. J Coastal Res 8:830-839

Defeo O, Brazeiro A, de Alava A, Riestra G (1997) Is sandy beach macrofauna only physically controlled? Role of substrate and competition in isopods. Estuar Coast Shelf Sci 45:453-462

Dexter D (1977) Natural history of the Pan-American sand beach isopod Excirolana braziliensis (Crustacea: Malacostraca). J Zool Lond 183:103-109

Dillery D, Knapp L (1969) Longshore movements of the sand crab, Emerita analoga (Decapoda, Hippidae). Crustaceana 18:233-240

Donn T (1987) Longshore distribution of Donax serra in two log-spiral bays in the Eastern Cape, South Africa. Mar Ecol Prog Ser 35:217-222

Donn T, Clarke D, McLachlan A, du Toit P (1986) Distribution and abundance of Donax serra Röding (Bivalvia: Donacidae) as related to beach morphology. I. Semilunar migrations. J Exp Mar Biol Ecol 102:121-131

Doyen J (1976) Marine beetles (Coleoptera excluding Staphylinidae). In: Chen L (ed) Marine insects. North-Holland Publishing Company, Amsterdam, p 497-520

Drapper N, Smith H (1981) Applied regression analysis. John Wiley \& Sons, New York

Dugan J, Hubbard D (1996) Local variations in populations of the sand crab Emerita analoga on sandy beaches in southern California. Rev Chil Hist Nat 69:579-588

Duggins D, Simenstad C, Estes J (1989) Magnification of secondary production by keIp detritus in coastal marine ecosystems. Science $245: 170-173$

Dye A, McLachlan A, Wooldridge T (1981) The ecology of sandy beaches in Natal, South Africa. S Afr J Zool 16: 200-209

Fallaci M, Colombini I, Chelazzi L (1994) An analysis of the coleoptera living along a Tyrrhenian beach-dune system: abundances, zonation and ecological indices. Vie Milieu 44:243-256

Gianuca N (1983) A preliminary account of the ecology of sandy beaches in southern Brazil. In: McLachlan A, Erasmus $T$ (eds) Sandy beaches as ecosystems. Junk, The Hague, p 413-420

Giménez L, Yannicelli B (1997) Variability of zonation patterns in temperate microtidal Uruguayan beaches with different morphodynamic types. Mar Ecol Prog Ser 160: 197-207

Goldsmith (1985) Coastal sand dunes. In: Davies R (ed) Coastal sedimentary environments. Elsevier, New York p 303-378

Griffiths C, Stenton-Dozey J, Koop K (1983) Kelp wrack and the flow of energy through a sandy beach ecosystem. In: McLachlan A, Erasmus T (eds) Sandy beaches as ecosystems. Junk, The Hague, p 547-556

Hurlbert S (1984) Pseudoreplication and the design of ecological field experiments. Ecol Monogr 54:187-211

Inglis $\mathrm{G}$ (1989) The colonization and degradation of stranded Macrocystis pyrifera (L.) C. Ag. by the macrofauna of a New Zealand sandy beach. J Exp Mar Biol Ecol 125: 203-217

Jaramillo E, McLachlan A (1993) Community and population responses of the macroinfauna to physical factors over a range of exposed sandy beaches in South-central Chile. Estuar Coast Shelf Sci 37:615-624
Jaramillo E, Pino M, Filun L, González M (1994) Longshore distribution of Mesodesma donacium (Bivalvia: Mesodesmatidae) on a sandy beach of the south of Chile. Veliger 37:192-200

Jones G, Ferrell D, Sale P (1990) Spatial patterns of abundance and structure of molluscs populations in the soft sediments of a coral reef lagoon. Mar Ecol Prog Ser 62: $109-120$

Josefson A (1987) Large-scale patterns of dynamics in subtidal macrozoobenthic assemblages in the Skagerrak: effects of a production-related factor? Mar Ecol Prog Ser 38:13-23

Lastra M, McLachlan M (1996) Spatial and temporal variations in recruitment of Donax serra Röding (Bivalvia Donacidae) on an exposed sandy beach of South Africa. Rev Chil Hist Nat 69:631-640

Legendre P (1993) Spatial autocorrelation: trouble or new paradigm. Ecology 74:1659-1673

Legendre P, McArdle B (1997) Comparison of surfaces. Oceanol Acta 20:27-41

Legendre $P$, Thrush $S$, Cummings $V$, Dayton $P$, Grant J, Hewitt J, Hines A, McArdle B, Pridmore R, Schneider D, Turner S, Whitlatch R, Wilkinson M (1997) Spatial structure of bivalves in a sandflat: scale and generating process. J Exp Mar Biol Ecol 216:99-128

Levin S (1992) The problem of pattern and scale in ecology. Ecology 73:1943-1967

Masselink G, Hegge B, Pattiaratchi C (1997) Beach cusp morphodynamics. Earth Surf Process Landforms 22:1139-1155

McArdle B, Blackwell R (1989) Measurement of density variability in the bivalve Chione stutchburyi using spatial autocorrelation. Mar Ecol Prog Ser 52:245-252

McLachlan A (1982) A model for the estimation of water filtration and nutrient regeneration by exposed sandy beaches. Mar Environ Res 6:37-47

McLachlan A (1988) Behavioural adaptations of sandy beach organisms: an ecological perspective. In: Chelazzi G, Vannini $M$ (eds) Behavioural adaptation to intertidal life. Plenium Publishing Corporation, New York, p 449-475

McLachlan A (1990) Dissipative beaches and macrofauna communities on exposed intertidal sands. J Coastal Res 6: $57-71$

McLachlan A (1996) Physical factors in benthic ecology: effects of changing sand particle size on beach fauna. Mar Ecol Prog Ser 131:205-217

McLachlan A, Hesp P (1984) Faunal response to morphology and water circulation of a sandy beach with cusps. Mar Ecol Prog Ser 19:133-144

McLachlan A, Jaramillo E (1995) Zonation on sandy beaches. Oceanogr Mar Biol Annu Rev 33:305-335

McLachlan A, Jaramillo E, Donn T, Wessels F (1993) Sandy beach macrofauna communities and their control by the physical environment: a geographical comparison. J Coastal Res Spec Issue 15:27-38

Menge B, Daley B, Wheeler P, Dahlhoff E, Sanford E, Strub P (1997) Benthic-pelagic links and rocky intertidal communities: bottom-up effects on top-down control? 'Proc Natl Acad Sci USA 94:14530-14535

Moore I, Legner E (1976) Intertidal rove beetles (Coleoptera: Staphylinidae). In: Chen L (ed) Marine insects. NorthHolland Publishing Company, Amsterdam, p 521-552

Morrisey D, Howitt L, Underwood A, Stark J (1992a) Spatial variation in soft-sediment benthos. Mar Ecol Prog Ser 81: 197-204

Morrisey D, Underwood A, Howitt L, Stark J (1992b) Temporal variation in soft sediment benthos. J Exp Mar Biol Ecol 164:233-245 
Naylor E, Rejeki S (1996) Tidal migrations and rhythmic behaviour of sand beach crustacea. Rev Chil Hist Nat 69: 475-484

Paine R (1974) Intertidal community structure: experimental studies on the relationship between a dominant competitor and its principal predator. Oecologia 15:93-120

Paine R, Levin S (1981) Intertidal landscapes: disturbance and the dynamics of the pattern. Ecol Monogr 51:145-178

Picket S, White P (1985) The ecology of natural disturbances and patch dynamics. Academic Press, London

Piñeiro G, Panario D (1993) Dinámica sedimentaria y geomorfológica de dunas y playas de Cabo Polonio. Internal Report, Fac de Ciencias, Universidad de la República, Montevideo

Rossi R, Mulla D, Journel A, Franz E (1992) Geostatistical tools for modeling and interpreting ecological spatial dependence. Ecol Monogr 62:277-314

Roughgarden J, Gaines S, Possingham H (1988) Recruitment dynamics in complex life cycles. Science 241:1460-1466

Simpson K (1976) Shore flies and brine flies (Diptera: Ephydridae). In: Chen L (ed) Marine insects. North-Holland Publishing Company, Amsterdam, p 465-495

Thrush S (1992) Spatial patterns in soft bottom communities. Trends Ecol Evol 6:75-79

Thrush S, Pridmore R, Bell R, Cummings V, Dayton P, Ford R, Grant J, Green M, Hewitt J, Hines A, Hume T, Lawrie $S$, Legendre P, McArdle B, Morrisey D, Schneider D, Turner $S$, Walters R, Whitlatch R, Wilkinson M (1997a) A sandflat habitat: scaling from experiments to conclusions. J Exp Mar Biol Ecol 216:1-9

Editorial responsibility: Otto Kinne (Editor),

Oldendorf/Luhe, Germany
Thrush S, Cumming V, Dayton P, Ford R, Grant J, Hewitt J, Hines A, Lawrie S, Pridmore R, Legendre $P$, McArdle B, Schneider D, Turner S, Whitlach R, Wilkinson M (1997b) Matching the outcome of small-scale density manipulation experiments with larger scale patterns as example of bivalve adult/juvenile interactions. J Exp Mar Biol Ecol 216:153-169

Turner S, Grant R, Pridmore R, Hewitt J, Wilkinson M, Hume T, Morrisey D (1997) Bedload and water-column transport and colonisation processes by post-settlement benthic macrofauna: does infaunal density matter? J Exp Mar Biol Ecol 216:51-75

Underwood A, Chapman M (1996) Scales of spatial patterns of distribution of intertidal invertebrates. Oecologia 107: 212-224

Wiens J (1989) Spatial scaling in ecology. Funct Ecol 3: 385-397

Wiens J, Addicott J, Case T, Diamond J (1986) Overview: the importance of spatial and temporal scale in ecological investigations. In: Diamond J, Case $\mathrm{T}$ (eds) Community ecology. Harper \& Row, New York, p 143-153

Yannicelli B (1998) Zonación de Excirolana armata Dana y Excirolana braziliensis Richardson (Isopoda: Cirolanidae) en playas arenosas micromareales: efectos de los ritmos de actividad, velocidad de enterramiento y capacidad de natación. MSc thesis, Universidad de la República, Montevideo

Zar JH (1996) Biostatistical analysis، 3rd edn. Prentice Hall International, Inc, Upper Saddle River, NJ

Submitted: August 11, 1999; Accepted: November 2, 1999 Proofs received from author(s): June 9, 2000 